\title{
The response of slow-growing chicks to the supplementations with different methionine levels and/or two types of enzymes
}

\author{
Youssef A. Attia ${ }^{1}$, El-Shohat A. Qota ${ }^{2}$, Abd E-Hamid E. Abd El- \\ Hamid $^{1}$ and Tarek A. Sadaka ${ }^{2}$ \\ ${ }^{1}$ Animal and Poultry Production Department, Faculty of Agriculture-Damanhour Branch, \\ Alexandria University, Damanhour 22516, Egypt ${ }^{2}$ Animal Production Research Institute, \\ Agriculture Research Center, Ministry of Agriculture, Dokki, Egypt
}

\begin{abstract}
In order to study productive performance and meat quality of slow-growing chicks used for rural poultry production in relation to methionine and enzyme supplementations, basal diets were formulated to contain $0.32,0.29$ and $0.27 \%$ methionine levels from 1 to $42 \mathrm{~d}$ of age, 43 to $84 \mathrm{~d}$ of age, and 85 to $98 \mathrm{~d}$ of age, respectively. These diets were supplemented with 0 , 0.06 and $0.12 \%$ of DL-methionine; thus, there were three methionine levels during each period. These levels were fed with or without 750 FTY of phytase- 6 or one $\mathrm{g} / \mathrm{kg}$ of multienzymes; thus there were three methionine levels by three enzyme treatments in factorial design. Methionine levels of $0.44,0.41$ and $0.33 \%$ significantly increased productive performance from 1 to 42,43 to 84 and 85 to $98 \mathrm{~d}$ of age, respectively. Phytase supplemented-basal diet and diet supplemented with $0.06 \%$ methionine and phytase yield similar productive performance to those of chicks fed diet supplemented with $0.06 \%$ and $0.12 \%$ methionine, respectively. Phytase improved significantly nutrient digestibilities, percentage dressed carcass and chest parts compared to the control and multienzymes groups. Increasing methionine levels by 0.06 and $0.12 \%$ improved significantly percentage dressed carcass, chest and hind parts by 2.2 and 2.7 , $1.4 \%$ and 2.8 and 3.1 and $2.5 \%$, respectively. However, the methionine level and/or type of enzyme supplementations did not significantly affect metabolic profiles such as plasma total protein, albumen, globulin, total lipids and cholesterol.
\end{abstract}

Keywords Enzymes; meat quality; methionine; productive-performance; slow-growing chicks

$$
\begin{aligned}
& \text { استجابة خلطان دجاج اللحم بطيئة النمو لإضافة مستويات مختلفة من المثيونين في }
\end{aligned}
$$

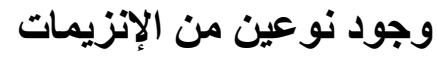

$$
\begin{aligned}
& \text { يوسف ع. عطية1، الشحات ع. قوطة2، عبدالحميد أ. عبدالحميد1، طارق أ. صدقة2 } \\
& \text { قسم الانتاج الحيواني والدواجن، كلية الزراعة فرع دمنهور، جامعة الاسكندرية، دمنهور 22516، جمهورية مصر العربية؛ } \\
& \text { معهد بحوث الانتاج الحيواني، مركز البحوث الزراعية، وزارة الزراعة، الدقي، جمهورية مصر العربية } \\
& \text { الملضص: تمت دراسة استجابة خلطان دجاج اللحم المحلية بطيء النمو لمستويات مختلفة من الميثيونين في وجود أو عدم الأن } \\
& \text { إضافة الإنزيمات علي الأداء الإنتاجي و معاملات الهضم و صفات الذبيحة و نوعية اللحم من حيث التحليل الكيماوي و ولئه }
\end{aligned}
$$

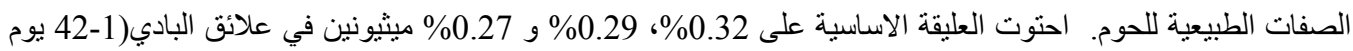

$$
\begin{aligned}
& \text { من العمر)، النامي (43-84 يوم من العمر) و الناهي (85-98 يوم من العمر)، وقد أضيف إلى العلف (صفر\%) ، } \\
& \text { \%) و (0.12\%) دل-ميثيونين في علائق البادي،النامي و الناهي، وكانت هنالك ثلاثة مستويات من الميثيونين لكل مرحلة. } \\
& \text { و هذة المستويات غذيت على علائق في وجود أو عدم وجود 750وحدة من إنزيم الفيتيز الميكروبي أو 1جم/كجم من مخلوط } \\
& \text { الإنزيمات وذللك في تصميم عاملي (3×3 ) اشتمل على ثلاث مستويات من الميثيونين و نو عين من الإنزيمات بالإضافة إلى عنى } \\
& \text { المجموعة الغير مضاف إليها. زادت مستويات الميثيونين (0.44، 0.41، 0.33) الاداء الانتاجي من } 1 \text { الى } 42 \text { ومن } 43 \text { اللى } 43 \text { ونى } \\
& 84 \text { ومن } 85 \text { الى } 98 \text { يوم بشكل منو الي. ادى إضافة } 750 \text { وحدة من إنزيم الفيتيز الميكروبي الي العليقة الاساسية و تللك } \\
& \text { المضاف اليها 060\% من الميثيونين الي تحسين الصفات الانتاجية. حسن الفيتيز الميكروبي من معامل الهضم الظاهري }
\end{aligned}
$$




$$
\begin{aligned}
& \text { للعناصر الغذائية و نسبة التصافي و نسبة الصدر مقارنة بمجموعة الكنترول و المجموعة المضاف اليها مخلوط الإنزيمات } \\
& \text { التجاري. زاد إضافة الميثيونين بمعدل } 0.06 \text { و 0.12\% معنويا من نسبة التصافي و الجزء الأمامي و الخلفي للذبيحة بمعدل } \\
& \text { 2.2، } 2.7 \text { و 1.4\% و 2.8، } 3.1 \text { و 2.5\% علي الترتيب بالمقارنة بمجموعة الكنترول، لم يؤثر مستوي الميثيونين و/أو }
\end{aligned}
$$

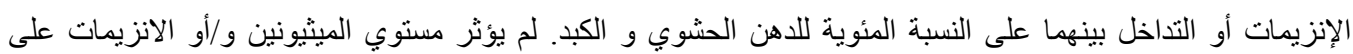

$$
\begin{aligned}
& \text { التحليل الكيماوي على محتوي بلازما الدم من البروتين و البومين و الجلوبين و الدهن و الكوليسترول و إنزيمات الكبد. } \\
& \text { الكلمات المفتاحية: إنزيمات، نوعية اللحم، ميثيونين، الأداء الإنتاجي، الاجاج بطيء النمو. }
\end{aligned}
$$

\section{Introduction}

Rural poultry production presents an important sector for agriculture development especially in the developing countries. In Egypt, $\sim 25-30 \%$ of poultry products are produced from the rural area using extensive, semi-intensive and backyard systems. Chickens reared under these conditions mostly suffer from malnutrition, especially for energy, protein/amino acids and minerals, due to poor quality of feeds and management, which contribute to low productive performance and economic benefits. In this regard, methionine requirements for broiler and leghorn type chicks are well documented (NRC, 1994). However, the requirements for slow-growing chicks used in rural production in the extensive, semi-intensive and backyard systems for optimum productive performance have received little attention. The Egyptian Ministry of Agriculture (1996) recommended that starter- growing diets from 1 to $56 \mathrm{~d}$ of age for native breeds may contain $17 \% \mathrm{CP}$ with $2750 \mathrm{kcal}$ $\mathrm{ME} / \mathrm{kg}$ diet, $0.9 \% \mathrm{Ca}, 0.40 \%$ available phosphorus, $0.85 \%$ lysine $(5 \%$ of $\mathrm{CP})$, $0.34 \%$ methionine $(2 \%$ of $\mathrm{CP})$. Meanwhile, the finisher diets from 57 to $84 \mathrm{~d}$ of age for native breeds may contain $15 \% \mathrm{CP}$ with $2900 \mathrm{kcal} \mathrm{ME} / \mathrm{kg}$ diet, $0.9 \%$ $\mathrm{Ca}, 0.40 \%$ available phosphorus, $0.70 \%$ lysine $(4.7 \%$ of $\mathrm{CP}), 0.30 \%$ methionine ( $2 \%$ of $\mathrm{CP})$. However, a recent study by Attia et al. (2005) indicated that slowgrowing chicks gained $14.6 \mathrm{~g} / \mathrm{d}$ from 1-56 $\mathrm{d}$ of age on a diet containing $0.42 \%$ methionine significantly improved productive performance, percentage dressed carcass and muscle crude protein $(\%)$, while they have significantly decreased abdominal fat compared to 0.32 and $0.37 \%$ dietary methionine level. Methionine is the first limiting amino acid in corn-soybean meal diet for chickens, due to low methionine contents of soybean meal. Methionine has a critical role in improving bird performance and nutrient utilizations. Thus, establishing methionine requirements for slowgrowing chicks could help to minimize feeding costs and nitrogen pollution and improved productive performance (Yonemochi et al., 2003 and Attia et al., 2005). However, methionine requirements are complicated by age and strain of birds, production level and physiological status, quality and level of dietary protein, and purpose of the production (Attia et al., 2005).

Multienzymes or phytase may be a practical mean to improve productive performance and utilization of low quality feeds and to overcome nutrient shortages (Attia et al., 2003a; b and Choct, 2006). Multienzymes containing $\beta$-glucanase, $\alpha$ amylase, cellulase, pectinase, xylanase, hemicellulase without or with protease and phytase could improve feed utilization and overcome the antinutritional factors of feedstuffs, and improve gut health and immune response (Yonemochi et al., 2003 and Choct, 2006). However, studies addressing the impact of enzymes on improving nutrient utilization of slow-growing chicks fed diets marginal in amino acids and phosphorus to overcome nutrient 
shortages is scarce (Attia, 2003a and Selle et al., 2006). Thus, the response of slowgrowing chicks to methionine and/or enzyme supplementation on productive performance and meat quality was investigated.

\section{Materials and Methods}

Experimental design, birds and diets

The experimental design was complete randomized factorial design including three levels of methionine/ sulphur amino acid (SAA) fed without or with multienzymes (Avizyme ${ }^{\circledR}$ 1500) and fungal phytase- 6 (Ronozyme ${ }^{\mathrm{TM}} \mathrm{P}$, product of Novo Nordisk and Roche). One unit (FTY) is equal to the enzyme activity that liberates $1 \mu \mathrm{mol}$ ortho-phosphate from 5.1 mmol of sodium phytate per minute at $37^{\circ} \mathrm{C}$ and $\mathrm{pH}$ 5.5. Its recommended dose of usage in broiler diets is $750 \mathrm{FTY} / \mathrm{kg}$. Avizyme $^{\circledR} 1500$ (a product of Finnfeed International LTD) was added at $1 \mathrm{~g} / \mathrm{kg}$. It is a multienzyme containing $4000 \mu / \mathrm{g}$ proteases, $300 \mu / \mathrm{g}$ of endo-1,4- $\beta$ xylanase, and $400 \mu / \mathrm{g}$ of $\alpha$-amylase). Thus, there were 9 experimental diets; each diet was fed to 60 one d; old unsexed slow-growing chicks gallus gallus $F$. Domestica (El-Salam chicks; Nchols $\times$ Mamorah [Alexandria \{Fayoumi $x$ Polymouth Rock $\times$ RIR $\times$ Leghorn $\} \times$ Dokki $_{4} \quad$ \{Parred Polymouth Rock $\times$ Fayoumi]) divided equally among four replicates of 15 chicks each housed in a floor pen $(1.5 \times 1.5 \mathrm{~m})$ furnished with rice hulls as litter. Chicks were wing banded and distributed randomly among the experimental diets at day of hatch, while keeping similar initial live body weight among replicates and teatments. Feed and water were offered ad libitum throughout the experiment.

The minimum ambient temperature during the experimental period from February to May 2004 ranged from 8.8 to $22.2^{\circ} \mathrm{C}$, whist the maximum ambient temeprature ranged from 19.6 to $41.3{ }^{\circ} \mathrm{C}$. Thus, the mean values \pm SE of minimum and maximum ambient temperature were $13.3 \pm 2.6$ and $26.7^{\circ} \mathrm{C} \pm 4.3$ respectively. Chicks were kept under similar managerial and hygienic conditions and illuminated with $23 \mathrm{~h}$ light/d.

A basal vegetable all-mash isocaloric and isonitrogenous diet was formulated to contain $0.32 / 0.65 \%, \quad 0.29 / 0.60 \%$ and $0.27 / 0.55$ methionine/SAA (negative control) during the starter- (1-42 d of age), grower- (43-84 d of age) and finisher period (85-98 $\mathrm{d}$ of age), respectively. Basal diets (Table 1) were supplemented or not supplemented with 0 , 0.06 and $0.12 \%$ of DL-methionine $(99 \%$ degussa- Hulls). These resulted in three levels of methionine/SAA in each period: $0.32 / 0.65, \quad 0.38 / 0.71$, and $0.44 / 0.77$; $0.29 / 0.60,0.35 / 0.66$, and $0.41 / 0.72$; and $0.27 / 0.55, \quad 0.33 / 0.61$, and $0.39 / 0.67$ respectively for the starter, grower and finisher diets. Methionine is the first limiting amino acid in corn-soybean meal diet for chickens, due to low methionine contents of soybean meal, and the calculation of the first limiting amino acid was methionine according to the broiler or White Leghorn chicks requirements (NRC, 1994). Additionally, these levels were fed without or with 750 FTY of Ronozyme phytase- 6 , or $1 \mathrm{~g} / \mathrm{kg}$ of Avizyme $1500^{\circledR}$. Available $\mathrm{P}$ and $\mathrm{Ca}$ percentages of phytase supplementeddiets were adjusted according to phytase equivalent level $(0.1 \%)$. Sand was added when needed to balance the experimental diets.

\section{Data collection}

Birds were weighed $(\mathrm{g})$ individually at 42, 84 and $98 \mathrm{~d}$ of age, and feed intake was recorded by replicate at the same time, and FCR was calculated on pen basis. The coefficient of apparent digestibility of nutrients of the total gut was determined using three replicates of two males each/treatment. Chicks were fasted for 24hours. Then they were fed on their corresponding experimental diets for 
72 hours, in which feed intake and excreta voided were accurately determined. The excreta was collected for each replicate, cleaned of feathers and feed, then weighed, and dried in a forced air oven at $70^{\circ} \mathrm{C}$ for $36 \mathrm{hr}$. Samples were then finally ground and placed in screw-top glass jars until analysis. The procedure described by Jakobson et al. (1960) was used for separating fecal nitrogen from urine nitrogen in excreta samples. CP, EE and $\mathrm{CF}$ content of the excrement as well as that of the feed were determined according to AOAC (1990), and expressed on a dry matter basis. The apparent digestibility of crude protein, fat, fibre and OM was calculated by dividing the daily amount retained $(\mathrm{g} / \mathrm{d})$ by the amount of intake $(\mathrm{g} / \mathrm{d})$. The daily amount retained is equal to the amount of intake $(\%$ nutrient in feed $\times$ amount of feed consumed) minus that voided in the excreta (\% nutrient in excreta, except for nitrogen of which the fecal nitrogen was used $\times$ amount of excreta voided).

At $98 \mathrm{~d}$ of age, 6 birds ( 3 males and 3 females) were taken randomly from each treatment, and slaughtered; the remaining carcasses after bleeding, plucking and eviscerating were weighed (dressed weight) and divided into chest and hind parts and weighed. Liver and abdominal fat were separated and individually weighed. The weights of carcass parts were expressed as relative to live body weigh. A sample of breast meat and thigh meat (50:50 basis) and also sample of liver were chemically analyzed for dry matter (DM), crude protein $(\mathrm{CP})$, ether extract (EE) and crude ash (CA) according to AOAC (1990). Meat tenderness and water holding capacity (WHC) were measured according to the method of Volvoinskaia and Kelman (1962). Colour intensity of the meat and drip were determined according to the method of Husani et al. (1950), whereas
$\mathrm{pH}$ value was measured by a $\mathrm{pH}$ meter as described by Aitken et al. (1962)

At $98 \mathrm{~d}$ of age, six blood samples were collected in heparinzed tubes from each treatment as three of each sex. Plasma was separated by centrifugation at $3000 \mathrm{rpm}$ for 15 minutes and stored at $20^{\circ} \mathrm{C}$ until analysis. Concentrations of total protein (Henry et al., 1974), albumin (Doumaset et al., 1977), total lipids (Chabrol and Charonnat, 1973), total cholesterol (Watson, 1960), alanine aminotransferase (ALT) and aspartate aminotransferase (AST) (Retiman and Frankel, 1957) were determined. Globulin was calculated by differences between total protein and albumin.

\section{Statistical analysis}

Data were analyzed using the GLM procedure of Statistical Analysis Software (SAS) version 6.11 (SAS ${ }^{\circledR}$ Institute, 1990, Cary, NC, USA) using two-way factorial design. The following model was used: $Y i j k=\mu+D i+P C j+(D \times P C) i j+e i j k$

where $Y i j k=$ the dependent variables; $\mu=$ general mean; $D i=$ effect of methionine; $P C j=$ effect of enzyme; $(D \times$ $P C) i j=$ effect of the interaction between methionine and enzyme treatment; and $e i$ $j k=$ random error. Before analysis, all percentages were subjected to logarithmic transformation $(\log 10 x+1)$ to approximate normal distribution. Mean difference at $p \leq 0.05$ was tested using Student-Newman-Keuls-Test. When a significant interaction $P$ value was obtained $(<0.05)$, mean differences were compared using LSD, and the values were presented in the tables. 
Emir. J. Food Agric. 2007. 19 (2): 48-63

http://www.cfa.uaeu.ac.ae/research/ejfa.htm

Table 1. Composition of the experimental basal diets \% (as fed basis) fed in the starter 1 to 42 $\mathrm{d}$ of age), grower 43-84 $\mathrm{d}$ of age) and finisher $85-98 \mathrm{~d}$ of age) periods.

\begin{tabular}{|c|c|c|c|}
\hline Ingredients (\%) & Starter diet & Grower diet & Finisher diet \\
\hline Maize & 60.00 & 66.52 & 68.97 \\
\hline Soybean meal (44\%) & 33.91 & 28.05 & 21.45 \\
\hline Wheat bran & 0.00 & 0.00 & 5.00 \\
\hline Limestone & 0.38 & 0.25 & 0.80 \\
\hline Bone meal & 2.32 & 2.30 & 1.41 \\
\hline Vit + Min Premix ${ }^{a}$ & 0.30 & 0.30 & 0.30 \\
\hline $\mathrm{NaCl}$ & 0.30 & 0.30 & 0.30 \\
\hline Clean sand & 0.34 & 0.68 & 0.22 \\
\hline Blend of vegetable oils & 2.45 & 1.60 & 1.55 \\
\hline \multicolumn{4}{|c|}{ Calculated and determined composition, $\%$} \\
\hline Dry matter ${ }^{\mathrm{b}}$ & 89.61 & 89.57 & 89.71 \\
\hline Metabolizable energy MJ/kg, ${ }^{c}$ & 12.55 & 12.55 & 12.55 \\
\hline Crude protein, $\%^{\mathrm{b}}$ & 19.75 & 17.84 & 15.78 \\
\hline Methionine, $\%{ }^{c}$ & 0.32 & 0.29 & 0.27 \\
\hline Methionine, $\%^{\mathrm{b}}$ & 0.33 & 0.28 & 0.25 \\
\hline Methionine + cystine, $\%^{\mathrm{b}}$ & 0.65 & 0.60 & 0.55 \\
\hline Lysine, $\%^{c}$ & 1.07 & 0.93 & 0.78 \\
\hline Lysine, $\%^{\mathrm{b}}$ & 1.05 & 0.90 & 0.80 \\
\hline Calcium, $\%^{\mathrm{c}}$ & 0.95 & 0.88 & 0.81 \\
\hline Avialable phosphorus, $\%^{\mathrm{c}}$ & 0.43 & 0.42 & 0.30 \\
\hline Crude fat, $\%^{\mathrm{b}}$ & 4.86 & 4.31 & 4.42 \\
\hline Crude fibre, $\%{ }^{\mathrm{b}}$ & 3.68 & 3.42 & 3.51 \\
\hline
\end{tabular}

${ }^{a}$ Vit+Min mixture provides per kilogram of diet: vitamin A retinyl acetate) $24 \mathrm{mg}$, vitamin E dl- $\alpha$ tocopheryl acetate) $20 \mathrm{mg}$, menadione $2.3 \mathrm{mg}$, Vitamin $\mathrm{D}_{3}$ cholecalciferol) $0.05 \mathrm{mg}$, riboflavin 5.5 $\mathrm{mg}$, calcium pantothenate $12 \mathrm{mg}$, nicotinic acid $50 \mathrm{mg}$, choline chloride $600 \mathrm{mg}$, vitamin $\mathrm{B}_{12} 10 \mu \mathrm{g}$, vitamin $\mathrm{B}_{6} 3 \mathrm{mg}$, thiamine $3 \mathrm{mg}$, folic acid $1 \mathrm{mg}$, d-biotin $0.50 \mathrm{mg}$. Trace mineral milligrams per kilogram of diet): $\mathrm{Mn} 80 \mathrm{Zn} 60, \mathrm{Fe} \mathrm{35,} \mathrm{Cu} 8$, Se $0.20 .{ }^{\mathrm{b}}$ Analyzed values, methionine and lysine was determined by amino acid analyze Degauss Hulls, Germany) ${ }^{\mathrm{c}}$ Calculated values.

\section{Results}

\section{Growth performance of chicks}

Table 2 shows the effect of different treatments on growth performance of ElSalam chicks. Growth was linearly increased and FCR was improved $(\mathrm{P}<0.05)$ from 1 to $42 \mathrm{~d}$ of age with increasing methionine levels. The improvements in BWG and FCR due to feeding of 0.38 and $0.44 \%$ methionine diets were 6.1 and $8.9 \%$ and 1.3 and $1.3 \%$ respectively, compared to the control group $(0.32 \%$ methionine $)$ Also, methionine levels of 0.35 and $0.41 \%$ significantly increased growth from 43 to $84 \mathrm{~d}$ of age by 2.3 and $6.0 \%$ respectively compared to the basal diets $(0.29 \%$ methionine level), while they linearly improved FCR by 4.9 and $7.1 \%$, meaning that the methionine level for optimum growth performance may be $0.44 \%$ or a higher level from 1 to $42 \mathrm{~d}$ of age. A methionine level of $0.35 \%$ significantly 
increased BWG from 85 to $98 \mathrm{~d}$ of age by 8.3 and $5.0 \%$ respectively compared to the control group $(0.29 \%$ methionine $)$ and $0.41 \%$ methionine group. However, $0.33 \%$ and $0.39 \%$ methionine levels had similar positive effect on FCR from 85 to $98 \mathrm{~d}$ of age compared to the control group $(0.27 \%$ methionine), showing that methionine level of $0.33 \%$ was adequate from 85 to $98 \mathrm{~d}$ of age. For the whole experimental period, BWG was linearly increased (4.7 and 6.6\%) and FCR was linearly improved (3.7 and 5.4\%) with increasing methionine levels, suggesting that higher levels of methionine should be tested in further research. In this regard, Attia et al., (2003a; 2005) indicated that slow-growing chicks used for rural production in extensive, semi-intensive and backyard system growing at $14.6 \mathrm{~g} / \mathrm{d}$ from 1 to $56 \mathrm{~d}$ of age could be fed a diet containing $0.42 \%$ methionine for optimum productive performance.

The results indicated that from 1 to 42 $\mathrm{d}$ of age both phytase and multienzymes significantly increased $\mathrm{BWG}$, while the impact of phytase was stronger $(5.2 \%)$ than the impact multienzymes $(1.7 \%)$. Phytase significantly improved growth of chicks by $2.3 \%$ compared to the control group from 43 to $84 \mathrm{~d}$ of age and by 5.2 and $5.4 \%$ respectively, compared with the control and multienzymes supplemented groups from 85-98 d of age. However, data revealed that from 1 to 42 and 43 to $84 \mathrm{~d}$ of age, only phytase significantly improved FCR by 3.1 and $2.2 \%$ and 4.4 and $2.9 \%$ respectively, compared to the control and multienzymes supplementedgroup.

There was no significant effect of multienzymes on BWG and FCR of chicks from 43 to 84 and 85 to $98 \mathrm{~d}$ of age or on FCR from 1 to $42 \mathrm{~d}$ of age. For the whole experimental period, BWG was significantly heavier and FCR was significantly better for the enzymesupplemented groups than for the control group, and the improvements in BWG and FCR due to phytase supplementation was more apparent $(3.8 \%)$ than for the multienzymes $(\sim 1.0 \%)$.

There were significant interactions between methionine level and enzyme addition on BWG from 1 to 42 , and 1 to $98 \mathrm{~d}$ of age and in FCR in the same periods besides 43 to $84 \mathrm{~d}$ of age. Results revealed that phytase significantly improved BWG by $6.8 \%$ and $5.3 \%$ of the control group $(0.32 \%$ methionine $)$ fed diet without or with 0.06 compared to their respective controls from 1 to $42 \mathrm{~d}$ of age respectively. The corresponding improvements in FCR were $4.8 \%$ and $3.5 \%$. Meanwhile, multienzymes significantly improved FCR by $1.7 \%$ of the control diet group from 1 to $42 \mathrm{~d}$ of age, respectively. Results indicated both enzymes had a non-significant influence on BWG and FCR of chicks fed the diet supplemented with $0.12 \%$ methionine from 1 to $42 \mathrm{~d}$ of age. Phytase significantly improved FCR of chicks fed the control diet and that supplemented with $0.06 \%$ methionine by $8.9 \%$ and $3.2 \%$ respectively, compared to their respective controls from 43 to $84 \mathrm{~d}$ of age.

For the whole experimental period, phytase significantly increased BWG by $5.0 \%$ and $4.6 \%$ and FCR by $6.6 \%$ and $3.5 \%$ of the control group fed diet without or with 0.06 compared to their corresponding controls respectively. In addition, phytase significantly improved FCR of the $0.12 \%$ of the methioninesupplemented diet group compared to their control. The corresponding improvements due to multienzymes on FCR were $2.3 \%$ and $1.0 \%$ of groups fed only the control diet without or with $0.06 \%$ methionine. Multienzymes had no significant effect on BWG and FCR for the complete experimental period of the group supplemented with $0.12 \%$ methionine. 
Emir. J. Food Agric. 2007. 19 (2): 48-63

http://www.cfa.uaeu.ac.ae/research/ejfa.htm

Table 2. Mean \pm SD for body weight gain ${ }^{A}$ (g/chick/period) and feed conversion ratio ${ }^{B}$ (kg feed/kg BWG) by supplemented methionine level and /or type of enzymes.

\begin{tabular}{|c|c|c|c|c|c|c|c|c|}
\hline \multirow{2}{*}{ Dietary treatments } & \multicolumn{4}{|c|}{ BWG (g\ chick \period) during } & \multicolumn{4}{|c|}{ FCR (g feed $\backslash$ g gain $\backslash$ period) during } \\
\hline & $1-42 d$ & $43-84 \mathrm{~d}$ & $85-98 \mathrm{~d}$ & $1-98 \mathrm{~d}$ & $1-42 \mathrm{~d}$ & $43-84 \mathrm{~d}$ & $85-98 \mathrm{~d}$ & $1-98 \mathrm{~d}$ \\
\hline \multicolumn{9}{|c|}{ Methionine supplementation (\%) } \\
\hline 0.09 & $463.6^{\mathrm{c}} \pm 20.9$ & $606.8^{\mathrm{C}} \pm 19.5$ & $209.4^{\mathrm{b}} \pm 21.8$ & $1279.8^{\mathrm{C}} \pm 35.4$ & $2.26^{\mathrm{a}} \pm 0.053$ & $3.24^{\mathrm{a}} \pm 0.107$ & $3.69^{\mathrm{a}} \pm 0.170$ & $2.96^{\mathrm{a}} \pm 0.089$ \\
\hline 0.06 & $492.1^{\mathrm{b}} \pm 24.2$ & $620.9^{\mathrm{b}} \pm 21.2$ & $226.8^{\mathrm{a}} \pm 20.9$ & $1339.8^{\mathrm{b}} \pm 36.3$ & $2.23^{\mathrm{b}} \pm 0.041$ & $3.08^{\mathrm{b}} \pm 0.044$ & $3.55^{\mathrm{b}} \pm 0.094$ & $2.85^{\mathrm{b}} \pm 0.043$ \\
\hline 0.12 & $504.8^{\mathrm{a}} \pm 20.0$ & $643.2^{\mathrm{a}} \pm 18.1$ & $215.9^{\mathrm{b}} \pm 23.0$ & $1363.9^{\mathrm{a}} \pm 27.5$ & $2.23^{\mathrm{b}} \pm 0.045$ & $3.01^{c} \pm 0.033$ & $3.49^{\mathrm{b}} \pm 0.074$ & $2.80^{c} \pm 0.024$ \\
\hline$P-$ Value & 0.0001 & 0.0001 & 0.001 & 0.0001 & 0.0001 & 0.0001 & 0.02 & 0.0001 \\
\hline \multicolumn{9}{|l|}{ Enzyme treatments } \\
\hline Without & $476.0^{\mathrm{C}} \pm 26.3$ & $616.6^{\mathrm{b}} \pm 21.3$ & $213.8^{\mathrm{b}} \pm 21.8$ & $1306.4^{\mathrm{C}} \pm 47.9$ & $2.27^{\mathrm{a}} \pm 0.041$ & $3.17^{\mathrm{a}} \pm 0.132$ & $3.60 \pm 0.186$ & $2.91^{\mathrm{a}} \pm 0.108$ \\
\hline Phytase & $500.7^{\mathrm{a}} \pm 26.1$ & $630.6^{\mathrm{a}} \pm 21.9$ & $224.9^{\mathrm{a}} \pm 21.6$ & $1356.2^{\mathrm{a}} \pm 38.6$ & $2.20^{\mathrm{b}} \pm 0.026$ & $3.03^{\mathrm{b}} \pm 0.040$ & $3.51 \pm 0.108$ & $2.80^{c} \pm 0.034$ \\
\hline Multienzymes & $483.9^{b} \pm 25.1$ & $623.8^{\mathrm{ab}} \pm 24.9$ & $213.3^{\mathrm{b}} \pm 23.7$ & $1321.0^{\mathrm{b}} \pm 44.6$ & $2.25^{\mathrm{a}} \pm 0.039$ & $3.13^{\mathrm{a}} \pm 0.103$ & $3.62 \pm 0.164$ & $2.88^{\mathrm{b}} \pm 0.072$ \\
\hline$P$-Value & 0.0001 & 0.01 & 0.02 & 0.0001 & 0.002 & 0.0003 & NS & 0.0001 \\
\hline \multicolumn{9}{|c|}{ Interaction between methionine supplementation (\%) and enzyme treatments } \\
\hline $0.0 \quad(-)$ & $448.7^{\mathrm{d}} \pm 14.3$ & $592.7 \pm 25.5$ & $211.9 \pm 20.9$ & $1253.3^{\mathrm{d}} \pm 22.3$ & $2.31^{\mathrm{a}} \pm 0.019$ & $3.38^{\mathrm{a}} \pm 0.019$ & $3.66 \pm 0.039$ & $3.05^{\mathrm{a}} \pm 0.014$ \\
\hline 0.0 Phytase & $479.0^{\mathrm{bc}} \pm 18.3$ & $617.9 \pm 19.1$ & $219.1 \pm 17.6$ & $1316.0^{\mathrm{C}} \pm 26.1$ & $2.20^{\mathrm{C}} \pm 0.015$ & $3.08^{\mathrm{d}} \pm 0.017$ & $3.61 \pm 0.087$ & $2.85^{\mathrm{d}} \pm 0.011$ \\
\hline 0.0 Multienzymes & $463.3^{\mathrm{cd}} \pm 17.7$ & $609.7 \pm 23.4$ & $197.1 \pm 18.9$ & $1270.1^{\mathrm{d}} \pm 21.9$ & $2.27^{\mathrm{b}} \pm 0.016$ & $3.26^{\mathrm{b}} \pm 0.054$ & $3.80 \pm 0.15$ & $2.98^{\mathrm{b}} \pm 0.010$ \\
\hline $0.06(-)$ & $481.2^{\mathrm{bc}} \pm 16.6$ & $613.0 \pm 16.3$ & $218.4 \pm 16.5$ & $1312.6^{\mathrm{C}} \pm 22.4$ & $2.27^{\mathrm{a}} \pm 0.027$ & $3.12^{\mathrm{C}} \pm 0.024$ & $3.60 \pm 0.045$ & $2.89^{c} \pm 0.014$ \\
\hline 0.06 Phytase & $506.9^{\mathrm{a}} \pm 22.9$ & $631.9 \pm 22.1$ & $233.9 \pm 23.4$ & $1372.7^{\mathrm{a}} \pm 28.4$ & $2.19^{\mathrm{b}} \pm 0.026$ & $3.02^{\mathrm{ef}} \pm 0.017$ & $3.48 \pm 0.104$ & $2.79^{f} \pm 0.005$ \\
\hline 0.06 Multienzymes & $488.1^{\mathrm{ab}} \pm 24.8$ & $618.0 \pm 20.2$ & $228.0 \pm 19.5$ & $1334.1^{\mathrm{bc}} \pm 28.1$ & $2.24^{\mathrm{a}} \pm 0.009$ & $3.09^{\mathrm{cd}} \pm 0.018$ & $3.58 \pm 0.091$ & $2.86^{\mathrm{d}} \pm 0.011$ \\
\hline $0.12(-)$ & $498.2^{\mathrm{ab}} \pm 17.9$ & $644.0 \pm 19.6$ & $211.0 \pm 24.7$ & $1353.2^{\mathrm{ab}} \pm 28.1$ & $2.23^{\mathrm{ab}} \pm 0.015$ & $3.00^{\mathrm{f}} \pm 0.031$ & $3.56 \pm 0.067$ & $2.81^{\mathrm{e}} \pm 0.007$ \\
\hline 0.12 Phytase & $516.2^{\mathrm{a}} \pm 20.7$ & $642.3 \pm 17.3$ & $221.9 \pm 21.3$ & $1380.4^{\mathrm{a}} \pm 23.1$ & $2.20^{\mathrm{ab}} \pm 0.036$ & $3.00^{f} \pm 0.028$ & $3.43 \pm 0.045$ & $2.77^{\mathrm{g}} \pm 0.007$ \\
\hline 0.12 Multienzymes & $500.0^{\mathrm{a}} \pm 16.4$ & $643.7 \pm 17.4$ & $214.7 \pm 21.8$ & $1358.4^{\mathrm{ab}} \pm 23.7$ & $2.25^{\mathrm{a}} \pm 0.066$ & $3.04^{\mathrm{e}} \pm 0.033$ & $3.49 \pm 0.052$ & $2.82^{\mathrm{e}} \pm 0.017$ \\
\hline $\boldsymbol{P}$-Value & 0.05 & NS & NS & 0.0001 & 0.03 & 0.004 & NS & 0.0001 \\
\hline LSD & 22.1 & --- & --- & 28.9 & 0.0373 & 0.0353 & --- & 0.0166 \\
\hline
\end{tabular}

${ }^{A} \mathrm{n}=180$ for any methionine and enzyme level, and 60 for any cell of the interaction.

${ }^{\mathrm{B}} \mathrm{n}=12$ for any methionine and enzyme level, and 4 for the any cell of the interaction.

$(-)=$ negative control.

$\mathrm{BWG}=$ body weight gain. $\mathrm{FCR}=$ feed conversion ratio. $\mathrm{CP}=$ crude protein. $\mathrm{EE}=$ ether extract. $\mathrm{CF}=$ crude fibre. $\mathrm{OM}=$ organic matter.

$\mathrm{NS}=$ not significant. LSD= least significant difference.

${ }_{\mathrm{a}, \mathrm{b}, \mathrm{c}, \mathrm{d}}$ Means within diet in the same row with different superscript letters are significantly different $(p<0.05)$ 


\section{Digestibility coefficients of nutrients}

Table 3 shows the impact of different dietary treatments on digestibility coefficients of nutrients. Although it was expected that increasing methionine level could improve total gut digestibility of nutrients and nitrogen retention due to improving dietary amino acids balance, there was a lack of its effect $(P>0.05)$ on digestibility of nutrients.

Phytase supplementation to corn soybean meal diets increased digestibility of CP, EE, CF, and OM compared to the control and multienzymes groups and thus could explain the improvement in the productive performance of phytase group. Multienzymes also improved digestibility of EE and OM compared to the control group, but to less extent than phytase.

The results showed that total gut digestibility of $\mathrm{CP}, \mathrm{EE}, \mathrm{CF}$, and $\mathrm{OM}$ was not significantly affected by the interaction between methionine and enzyme supplementations. However, phytase supplemented groups exhibited consistently higher $\mathrm{CP}, \mathrm{EE}, \mathrm{CF}$, and $\mathrm{OM}$ digestibility, and this coincided with the improved productive performance of these groups.

\section{Meat quality}

Tables 3 and 4 show the influence of dietary treatments on carcass characteristics and chemical composition and physical parameters of meat respectively. It was found that methionine supplementation at either 0.06 or $0.12 \%$ significantly improved percentage of dressed carcass; chest and hind part by $2.2,1.4$, and $3.1 \%$, and $2.7,2.8$, and $2.5 \%$ respectively, compared to the control group. However, differences between 0.06 and $0.12 \%$ methionine levels were not significant. Results indicated that there was no significant interaction between methionine and enzyme supplementations on the relative weight of dressed carcass, chest and hind part, abdominal fat or liver (Table 3).

Phytase improved dressed carcass percentage $(\mathrm{P}<0.05)$ and chest $(\mathrm{P}<0.07)$ by 1.6 and $2.2 \%$ respectively, compared to the control, and by similar extent i.e. 1.7 and $2.6 \%$ respectively, compared to the multienzymes supplemented-group. The multienzymes group exhibited no significant differences from the control group. Phytase or multienzymes had no significant effects on percentage of hind part, abdominal fat, or liver.

The results indicated that there was no significant influence due to methionine level and/or enzyme addition on percentage $\mathrm{CP}$ and $\mathrm{EE}$ of muscle tissue and liver. Most of the physical characteristics of meat e.g. colour intensity, tenderness and WHC of muscle were not affected by methionine, enzyme and the interaction between methionine and enzyme supplementations. However, $0.12 \%$ methionine supplementation significantly increased the $\mathrm{pH}$ value of muscle tissue, which might be due to increasing lactic acid production.

\section{Metabolic profile}

Table 5 shows the effect of different levels of methionine and/or type of enzymes on the metabolic profile. The results reveal that methionine level and / or enzyme supplementation did not significantly affect plasma constituents, showing a lack of positive effect of dietary treatments and/or adequacy of the basal experimental on plasma total proteins, albumen, globulin, total lipids and cholesterol. 
Emir. J. Food Agric. 2007. 19 (2): 48-63

http://www.cfa.uaeu.ac.ae/research/ejfa.htm

Table 3. Mean \pm SD for apparent digestibility of nutrients ${ }^{\mathrm{A}}(\%)$ and carcass characteristics ${ }^{\mathrm{B}}(\%)$ by supplemented methionine level and /or type of enzymes.

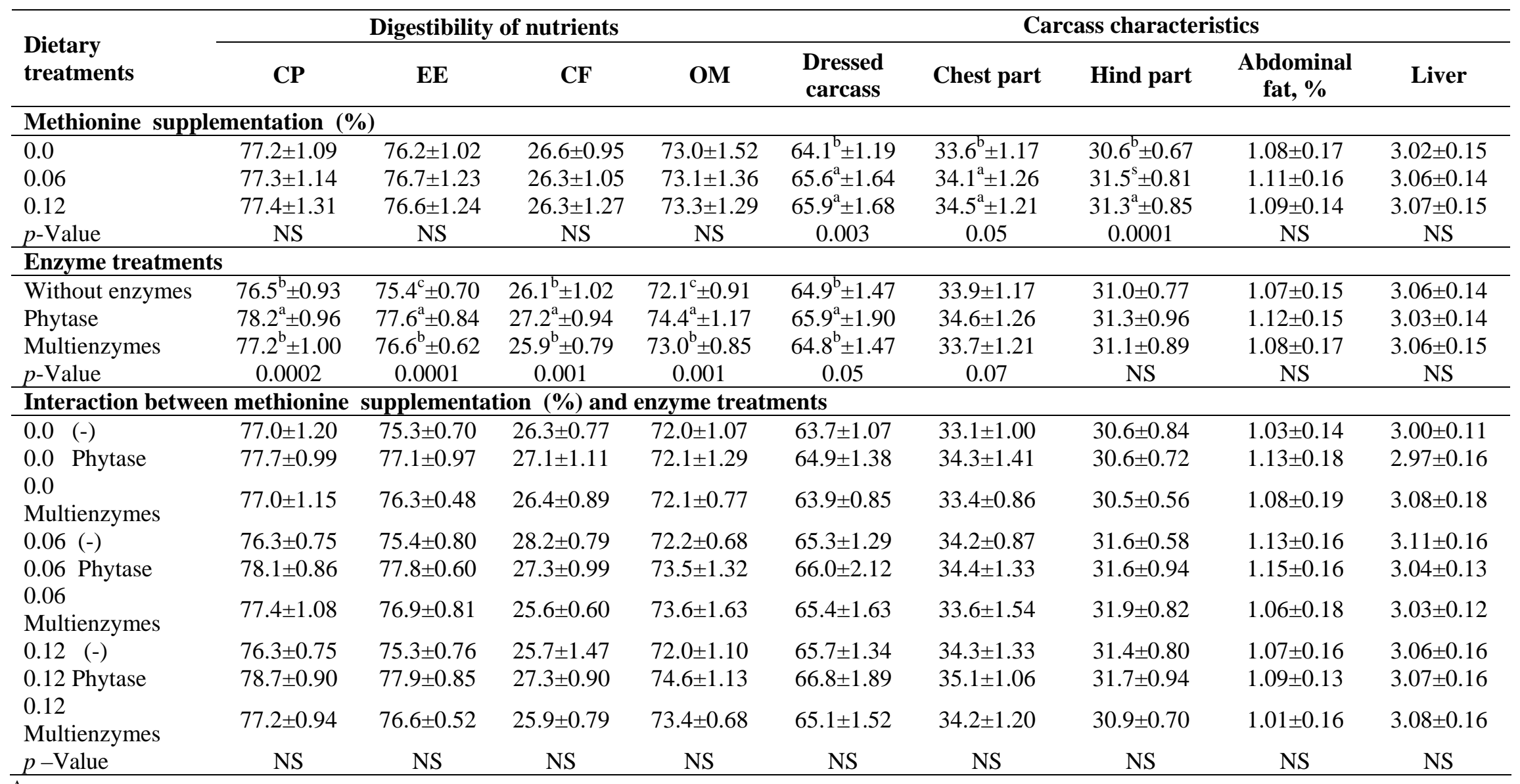

${ }_{\mathrm{A}} \mathrm{n}=9$ for any methionine and enzyme level, and 3 for any cell of the interaction.

${ }^{\mathrm{B}} \mathrm{n}=18$ for any methionine and enzyme level, and 6 for any cell of the interaction.

$(-)=$ Negative control.

NS=Not significant.

${ }_{\mathrm{a}, \mathrm{b}}$ Means within diet in the same row with different superscript letters are significantly different $(p<0.05)$ 
Youssef A. Attia et al.

Table 4. Mean \pm SD for protein and lipid percentage ${ }^{A}$ of mmuscle and liver and physical characteristics ${ }^{A}$ of meat by supplemented methionine level and /or type of enzymes.

\begin{tabular}{|c|c|c|c|c|c|c|c|c|}
\hline \multirow{2}{*}{ Dietary treatments } & \multicolumn{2}{|c|}{$\begin{array}{l}\text { Chemical composition of } \\
\text { muscle }\end{array}$} & \multicolumn{2}{|c|}{$\begin{array}{l}\text { Chemical composition of } \\
\text { Liver }\end{array}$} & \multicolumn{4}{|c|}{ Physical characteristics of meat } \\
\hline & $\begin{array}{c}\text { Ether } \\
\text { extract }\end{array}$ & $\begin{array}{c}\text { Crude } \\
\text { protein }\end{array}$ & Ether extract & $\begin{array}{c}\text { Crude } \\
\text { protein }\end{array}$ & $\mathbf{p H}$ & Colour & Tenderness & WHC \\
\hline \multicolumn{9}{|c|}{ Methionine supplementation (\%) } \\
\hline 0.0 & $16.4 \pm 0.90$ & $75.6 \pm 0.86$ & $23.1 \pm 0.82$ & $67.8 \pm 0.86$ & $6.52^{\mathrm{b}} \pm 0.10$ & $0.21 \pm 0.023$ & $2.51 \pm 0.17$ & $5.93 \pm 0.17$ \\
\hline 0.06 & $15.9 \pm 0.90$ & $76.1 \pm 0.91$ & $22.1 \pm 0.95$ & $67.8 \pm 0.84$ & $6.52^{\mathrm{b}} \pm 0.12$ & $0.21 \pm 0.015$ & $2.57 \pm 0.12$ & $5.97 \pm 0.20$ \\
\hline 0.12 & $16.1 \pm 0.87$ & $75.9 \pm 0.88$ & $23.2 \pm 0.99$ & $67.7 \pm 1.05$ & $6.61^{\mathrm{a}} \pm 0.088$ & $0.21 \pm 0.018$ & $2.59 \pm 0.09$ & $5.98 \pm 0.19$ \\
\hline$p-$ Value & NS & NS & NS & NS & 0.0001 & NS & NS & NS \\
\hline \multicolumn{9}{|l|}{ Enzyme treatments } \\
\hline Without enzymes & $16.1 \pm 0.93$ & $75.8 \pm 0.90$ & $23.1 \pm 0.79$ & $67.9 \pm 0.83$ & $6.54 \pm 0.12$ & $0.21 \pm 0.017$ & $2.54 \pm 0.14$ & $5.99 \pm 0.19$ \\
\hline Phytase & $15.9 \pm 0.88$ & $76.2 \pm 0.91$ & $22.2 \pm 0.94$ & $67.6 \pm 0.90$ & $6.53 \pm 0.09$ & $0.21 \pm 0.017$ & $2.59 \pm 0.15$ & $5.95 \pm 0.18$ \\
\hline Multienzymes & $16.5 \pm 0.85$ & $75.7 \pm 0.86$ & $23.1 \pm 0.99$ & $67.9 \pm 1.00$ & $6.57 \pm 0.12$ & $0.22 \pm 0.022$ & $2.55 \pm 0.12$ & $5.94 \pm 0.19$ \\
\hline$p$-Value & NS & 0.07 & NS & NS & NS & NS & NS & NS \\
\hline \multicolumn{9}{|c|}{ Interaction between methionine supplementation (\%) and enzyme treatments } \\
\hline $0.0 \quad(-)$ & $16.5 \pm 1.05$ & $75.6 \pm 0.99$ & $22.8 \pm 0.65$ & $67.9 \pm 0.91$ & $6.50 \pm 0.12$ & $0.21 \pm 0.017$ & $2.46 \pm 0.14$ & $5.92 \pm 0.20$ \\
\hline 0.0 Phytase & $16.1 \pm 0.89$ & $75.8 \pm 0.96$ & $23.4 \pm 0.85$ & $67.5 \pm 0.93$ & $6.52 \pm 0.09$ & $0.20 \pm 0.016$ & $2.63 \pm 0.17$ & $5.97 \pm 0.17$ \\
\hline 0.0 Multienzymes & $16.7 \pm 0.78$ & $75.4 \pm 0.74$ & $23.0 \pm 0.98$ & $68.1 \pm 0.79$ & $6.53 \pm 0.10$ & $0.22 \pm 0.033$ & $2.46 \pm 0.16$ & $5.89 \pm 0.17$ \\
\hline $0.06(-)$ & $15.7 \pm 0.71$ & $75.9 \pm 0.80$ & $24.3 \pm 0.71$ & $67.7 \pm 0.84$ & $6.47 \pm 0.10$ & $0.22 \pm 0.015$ & $2.63 \pm 0.13$ & $6.00 \pm 0.24$ \\
\hline 0.06 Phytase & $15.8 \pm 1.08$ & $76.5 \pm 1.01$ & $19.8 \pm 0.83$ & $67.8 \pm 0.90$ & $6.53 \pm 0.12$ & $0.20 \pm 0.013$ & $2.50 \pm 0.14$ & $5.99 \pm 0.23$ \\
\hline 0.06 Multienzymes & $16.2 \pm 0.91$ & $75.9 \pm 0.96$ & $23.2 \pm 0.95$ & $68.0 \pm 0.92$ & $6.55 \pm 0.14$ & $0.22 \pm 0.014$ & $2.59 \pm 0.06$ & $5.93 \pm 0.13$ \\
\hline $0.12(-)$ & $16.0 \pm 0.93$ & $76.0 \pm 1.02$ & $23.2 \pm 0.95$ & $67.9 \pm 0.88$ & $6.64 \pm 0.07$ & $0.20 \pm 0.014$ & $2.53 \pm 0.10$ & $6.07 \pm 0.11$ \\
\hline 0.12 Phytase & $15.9 \pm 0.77$ & $76.2 \pm 0.74$ & $23.3 \pm 0.95$ & $67.4 \pm 0.99$ & $6.54 \pm 0.08$ & $0.22 \pm 0.016$ & $2.63 \pm 0.12$ & $5.89 \pm 0.16$ \\
\hline 0.12 Multienzymes & $16.4 \pm 0.93$ & $75.7 \pm 0.94$ & $23.2 \pm 1.21$ & $67.7 \pm 1.37$ & $6.64 \pm 0.09$ & $0.22 \pm 0.018$ & $2.59 \pm 0.06$ & $5.98 \pm 0.26$ \\
\hline$p-$ Value & NS & NS & NS & NS & NS & NS & NS & NS \\
\hline
\end{tabular}

${ }^{\mathrm{A}} \mathrm{n}=18$ for any methionine and enzyme level, and 6 for any cell of the interaction.

$(-)=$ Negative control.

NS= Not significant.

${ }^{a, b}$ Means within diet in the same row with different superscript letters are significantly different $(p<0.05)$

$\mathrm{pH}=$ hydrogen power (degree of acidity). WHC= water holding capacity. 
Emir. J. Food Agric. 2007. 19 (2): 48-63

http://www.cfa.uaeu.ac.ae/research/ejfa.htm

Table 5. Mean \pm SD for plasma biochemical constituents by methionine level and /or type of enzymes.

\begin{tabular}{|c|c|c|c|c|c|c|c|}
\hline \multirow[b]{2}{*}{ Dietary treatments } & \multicolumn{7}{|c|}{ Plasma biochemical constituents } \\
\hline & $\begin{array}{c}\text { Total } \\
\text { protein } \\
\text { (g\100 ml) }\end{array}$ & $\begin{array}{c}\text { Albumin } \\
\text { (g\100ml) }\end{array}$ & $\begin{array}{l}\text { Globulin } \\
\text { (g\100 ml) }\end{array}$ & $\begin{array}{l}\text { Total lipids } \\
\text { (mg\100 ml) }\end{array}$ & $\begin{array}{c}\text { Total } \\
\text { cholesterol } \\
(\mathrm{mg} \backslash 100 \mathrm{ml})\end{array}$ & $\operatorname{AST}(\mu \backslash \mathbf{L})$ & $\operatorname{ALT}(\mu \backslash \mathbf{L})$ \\
\hline \multicolumn{8}{|c|}{ Methionine supplementation (\%) } \\
\hline 0.0 & $4.46 \pm 0.385$ & $2.30 \pm 0.203$ & $2.16 \pm 0.187$ & $759 \pm 38.4$ & $177 \pm 6.160$ & $23.14 \pm 1.648$ & $11.10 \pm 1.537$ \\
\hline 0.06 & $4.49 \pm 0.415$ & $2.29 \pm 0.242$ & $2.20 \pm 0.179$ & $754 \pm 38.3$ & $178 \pm 5.895$ & $22.27 \pm 2.164$ & $10.99 \pm 1.481$ \\
\hline 0.12 & $4.52 \pm 0.515$ & $2.33 \pm 0.298$ & $2.19 \pm 0.222$ & $750 \pm 50.2$ & $180 \pm 7.082$ & $22.33 \pm 2.427$ & $11.17 \pm 1.452$ \\
\hline$p$-Value & NS & NS & NS & NS & NS & NS & NS \\
\hline \multicolumn{8}{|l|}{ Enzyme treatments } \\
\hline Without & $4.51 \pm 0.510$ & $2.32 \pm 0.300$ & $2.19 \pm 0.213$ & $753 \pm 38.1$ & $178 \pm 6.002$ & $22.54 \pm 1.981$ & $11.15 \pm 1.585$ \\
\hline Phytase & $4.50 \pm 0.420$ & $2.32 \pm 0.232$ & $2.18 \pm 0.196$ & $749 \pm 51.0$ & $179 \pm 6.504$ & $22.54 \pm 2.213$ & $11.27 \pm 1.559$ \\
\hline Multienzymes & $4.47 \pm 0.389$ & $2.29 \pm 0.212$ & $2.18 \pm 0.182$ & $761 \pm 36.8$ & $179 \pm 6.902$ & $22.67 \pm 2.227$ & $10.84 \pm 1.277$ \\
\hline$p$-Value & NS & NS & NS & NS & NS & NS & NS \\
\hline \multicolumn{8}{|c|}{ Interaction between methionine supplementation (\%) and enzyme treatments } \\
\hline 0.0 & $4.44 \pm 0.404$ & $2.28 \pm 0.213$ & $2.16 \pm 0.192$ & $750 \pm 42.4$ & $175 \pm 5.728$ & $22.80 \pm 1.404$ & $11.06 \pm 1.697$ \\
\hline 0.0 Phytase & $4.46 \pm 0.437$ & $2.30 \pm 0.217$ & $2.16 \pm 0.232$ & $771 \pm 33.9$ & $179 \pm 7.277$ & $23.10 \pm 1.558$ & $11.08 \pm 1.857$ \\
\hline 0.0 Multienzymes & $4.49 \pm 0.383$ & $2.32 \pm 0.216$ & $2.17 \pm 0.168$ & $757 \pm 41.9$ & $177 \pm 5.997$ & $23.54 \pm 2.122$ & $11.17 \pm 1.304$ \\
\hline 0.06 ----- & $4.45 \pm 0.465$ & $2.27 \pm 0.247$ & $2.18 \pm 0.218$ & $752 \pm 40.7$ & $178 \pm 6.318$ & $22.34 \pm 2.353$ & $11.36 \pm 1.605$ \\
\hline 0.06 Phytase & $4.54 \pm 0.454$ & $2.35 \pm 0.281$ & $2.19 \pm 0.175$ & $753 \pm 38.0$ & $179 \pm 5.579$ & $22.07 \pm 2.564$ & $11.00 \pm 1.456$ \\
\hline 0.06 Multienzymes & $4.47 \pm 0.400$ & $2.27 \pm 0.230$ & $2.20 \pm 0.171$ & $757 \pm 43.2$ & $179 \pm 6.789$ & $22.41 \pm 1.934$ & $10.63 \pm 1.562$ \\
\hline 0.12 & $4.64 \pm 0.688$ & $2.41 \pm 0.429$ & $2.23 \pm 0.259$ & $757 \pm 38.1$ & $180 \pm 6.195$ & $22.47 \pm 2.387$ & $11.05 \pm 1.737$ \\
\hline 0.12 Phytase & $4.49 \pm 0.445$ & $2.31 \pm 0.234$ & $2.18 \pm 0.212$ & $723 \pm 69.7$ & $179 \pm 7.723$ & $22.46 \pm 2.647$ & $11.74 \pm 1.517$ \\
\hline 0.12 Multienzymes & $4.44 \pm 0.455$ & $2.28 \pm 0.227$ & $2.16 \pm 0.231$ & $770 \pm 28.9$ & $181 \pm 8.233$ & $22.08 \pm 2.686$ & $10.73 \pm 1.098$ \\
\hline$p$-Value & NS & NS & NS & NS & NS & NS & NS \\
\hline
\end{tabular}

ALT $=$ Alanine-amino-transferase. AST $=$ Aspartate-amino-transferase. $\mathrm{P}$ value $=$ probability value. . 


\section{Discussion}

The present results indicated that methionine supplementation improved growth performance and this is in agreement with the results reported by Attia et al. (2005). It is clear that the optimal treatment observed herein is 0.44 (2.2\% of CP), 0.41 (2.3\% of CP) and $0.33 \%$ (2.1\% of CP) methionine from 1 to 42,43 to 84 and 85 to $98 \mathrm{~d}$ of age respectively for slow-growing chicks used for meat production under extensive, semi-intensive production and back yard systems. These levels are higher than the methionine level recommended by the Egyptian Ministry of Agriculture (1996) of 0.34 (2\% of CP) and 0.30 (2\% of CP) from 1 to 56 and 57 to $84 \mathrm{~d}$ of age respectively. The lower $\mathrm{CP} /$ methionine recommendation by Egyptian Ministry of Agriculture (1996) could limit the expression of genetic potentiality of these type of chicks and economic benefits for small holders. However, in the present study we used higher protein levels i.e. 20, 18 and $16 \%$ in the starter, grower and finisher diets. However, the methionine level was similar when expressed relative to dietary CP level (Table 1). In this regard, the recommended levels of CP (Egyptian Ministry of Agriculture, 1996) were 17 and $15 \%$ CP from 1 to 56 and 57 to $84 \mathrm{~d}$ of age respectively.

It was found that phytase is more potent for improving BWG and FCR than multienzymes. However, the effect of phytase could not be totally attributed to the improvements in the availability of methionine and/or other amino acids, but also to the multi-nutritional effects of phytase and the other side effects of the microbial body of phytase producing organisms (Ravindran et al., 1999; Attia 2003a;b, Saleh et al., 2004; Yonemochi et al., 2003; Choct, 2006; Selle et al., 2006; Panda et al., 2007). In this regard, phytase was found (Wu et al., 2004) to reduce digesta viscosity in the duodenum and ileum but not in the jejunum, and it increased the villus height in the duodenum and decreased the number of goblet cells in the jejunum (improving absorption) compared with those on the unsupplemented basal diet. However, Saleh et al., (2004) indicated that cellulase phytase, proteases, glucanase, hemicellulase, xylanase had no effect on viscosity of corn in the peptic and pancreatic phases. In this regard, Saleh et al., (2004) and Choct (2006) concluded that enzymes improved digestibility of nutrients. Moreover, Yonemochi et al., (2003) showed that phytase decreased significantly $\mathrm{N}$ and $\mathrm{DM}$ excretion by 30 and $18 \%$ respectively, and was more potent than multienzymes. Thus, the positive effect of phytase on performance of chicks could also ascribed to the improvement in digestibility of nutrients compared to the effect of multienzymes which exhibited a small effect only on digestibility of EE and OM (Table 3). Furthermore, the effect of enzymes (xylanase) may also be due to its contribution to gut health (Choct, 2006), which might be a problem under rural production due to low hygiene levels. Thus, phytase could improve productive performance of chicks with marginal nutritional deficiencies (Attia, 2003a; b; Yonemochi et al., 2003; Panda et al., 2007).

The small effect of multienzymes compared to phytase observed herein could be explained by the results of Saleh et al. (2004). These authors observed that proteases contents of multienzymes might be detrimental to other enzymes in the cocktail, and thus decrease the effect of enzyme cocktail containing proteases. However, Wu et al. (2004) concluded that phytase improved BWG and FCR by 17.5 and $2.9 \%$ respectively; meanwhile the corresponding improvements due to the addition of xylanase were 16.5 and $4.9 \%$ respectively. Juanpere et al. (2005) reported that phytase increased intestinal viscosity and AME in corn diets. 
However, Yonemochi et al., (2003) found that phytase and multienzymes had no effect on FCR.

The present results indicated that the impact of phytase and multienzymes is dependent on methionine level and phytic acids of the experimental diets, and decreased with increasing dietary methionine concentration, and age of chicks. In this regard, phytase may form complexes with protein/amino acid with those already in feedstuffs (Ravindran et al., 1995) or those formed de novo formatted in the digestive tract (Jongbloed et al., 1997), and with free amino acids in the digestive tract (Rutherfurd et al., 1997). Also, Attia (2003a;b) reported that the impact of phytase depends on either level of methionine or lysine, and phytase improved growth performance of broilers fed diets containing marginal levels of protein/amino acid and ME (Ravindran et al. (1999).

The addition of an enzyme cocktail to a corn -soybean diet has often shown to improve performance of chickens (Kocher et al., 2002; Saleh et al., 2004). In this regard, Cowieson (2005) speculated that the ability of enzymes, in particular glucanases, to enhance the nutritive value of some corn-soy diets is probably mediated through changes in cell wall architecture of the grain rather than viscosity decrease as it is often the case for viscous grain (Choct, 2006). The decrease in response to enzymes with increasing age of chicks could be attributed to maturity of the digestive tract in terms of improvement in enzyme secretion and capacity and ecology of the gut (Attia, 2003a and Choct, 2006).

The increase in carcass yield due to methionine supplementation was concurred with the improvement in BWG (Tables 2 and 3). Also, the results of Schutte et al. (1997) and Attia et al. (2005) indicated that methionine supplementation to corn soybean meal diets to either fast or slow growing chicks (scavenging) significantly improved carcass yield and breast meat yield. The lack of significant effect of methionine supplementation on abdominal fat and liver percentage (Table 3) and meat lipid (Table 4) are unexpected findings due to the well-known effect of methionine as a lipotropic agent, and indicated strain differences in lipid metabolism. In this regard, methionine supplementation to broilers (Esteve-Garcia and Mack, 2000), and slow growing Mandarah strain (Attia et al., 2005) significantly decreased abdominal fat percentage.

The significant improvement in dressing and chest percentage (Table 3) due to phytase coincided with the improvement in availability of nutrient for growth (Table 3). This is in line with the conclusion of Selle et al., (2006) and Attia (2003a;b). The lack of significant effect of dietary treatments on the chemical composition of meat and thus on physical characteristics of meat (Table 4) indicates that growth is the first parameter to be influenced by marginal nutrient deficiency e.g. of methionine. These results are in concert with those reported by Attia (2003a;b) who observed that percentages of DM, CP, EE and CA of meat and physical characteristics were not significantly affected by the interaction between lysine or methionine and phytase supplementation.

Blood profiling, initially used to detect subclinical disorders due to incorrect feeding, has recently been given more widely to evaluate the effects of different treatments on metabolic, nutritional and welfare conditions of animals (Bovera et al., 2006). In the past, bovines were studied extensively but now, given the interest of the scientific community, metabolic profiles are studied in all livestock species. The absence of significant treatment effects on plasma constituents are in line with those reported by Attia et al. (2003 a, b) and Bovera et al. (2006), and indicate the adequacy of nutrient contents in the basal experimental diets. 


\section{Conclusion}

Slow-growing chicks used for rural production gained $\sim 14 \mathrm{~g} / \mathrm{d}$ from 1-98 d of age may be fed corn-soybean meal diets containing $0.44 / 0.77, \quad 0.41 / 0.72$ and $0.33 / 0.61 \%$ methionine/SAA from 1 to 42,43 to 84 and 85 to $98 \mathrm{~d}$ of age respectively. However, these levels may be decreased to $0.38 / 0.71,0.35 / 0.68$ and $0.27 / 0.55 \%$ methionine/SAA with supplementation of 750 FTY microbial phytase/kg diets, which might provide a practical means to increase growth under rural poultry production due to the multinutritional effects of phytases.

\section{References}

Aitken, A., J. C. Casey, I. F. Penny and C. A. Volys. 1962. Effect of drying temperature in the accelerated freezes drying of pork. Journal Science Food Agriculture. 13:439.

Association of Official Analytical Chemists AOAC. 1990. Official methods of analysis. $15^{\text {th }}$ edition, Arlington, Virginia, USA.

Attia, Y. A. 2003a. Responses of growth performance, carcass characteristics, meat quality, and plasma constituents of male Campbell ducks to dietary levels of methionine and phytase and their interactions. Egyptian Poultry Science. 23:557580.

Attia, Y. A. 2003b. Performance, carcass characteristics, meat quality, and plasma constituents of meat type drakes fed diets containing different level of lysine with or without microbial phytase. Archiv Animal Nutrition. 56:39-48.

Attia, Y. A., R. A. Hassan, M. A. Shehatta and B. Abd EL-Hady, Slawa. $2005 . \quad$ Growth, characteristics, and serum constituents of slow growing chicks as affected by betaine addition to diets containing 2. Different levels of methionine. International Journal of Poultry Science. 4:858-865.

Bovera, F., G. Moniello, N. De riu, C. Di meo, W. Pinna, and A. Nizza. 2007. Effect of diet on metabolic profile of ostriches (Struthio camelus var. domesticus). Tropical Animal Health and Production. 34 (4):265-270.

Chabrol, E. and R. Charonnat.1973. Determination of total lipids. Press medical. 45:1713-1720.

Choct, M. 2006. Enzymes for the feed industry, past, present and future. World's Poultry Science Journal. 62:5-15.

Cowieson, A. J. 2005. Factors that affect the nutritional value of maize for broilers. Animal Feed Science and Technology. 119:293-305.

Doumas, B. T., D. Watson and H. G. Biggs. 1977. Albumins standards and the measurement of blood albumin with bromocrisol green. Clinical Chemist Acta. 31:87.

Egyptian Ministry of Agriculture. 1997. Ministry decision number 1498 for 1996 for regulations of feeds, feeds manufactures, handling, and quality control affairs.

Esteve-Garcia, E. and S. Mack. 2000. The effect of DL-methionine and betaine on growth performance and carcass characteristics in broilers. Animal Feed Science and Technology. 87:85-93.

Henry, R., D. Cannon and J. Winkelman. 1974. Clinical chemist principles and techniques, $2^{\text {nd }}$ Edn. Ha-per and Row. 
Husani, S. A., F. B. Deatherage and L. E. Kunlkle. 1950. Studies on meat.11, Observations on relation of biochemical factors to change in tenderness. Feed Technology. 4:366-369.

Jakobson, P. E., S. G. Kirston and M. Nelson. 1960. Digestibility trials with poultry. 322 bertning fraforsgs laboratories, udgivct of slants. Husdyrbugsudvalg-K.abcnhavn.

Jongbloed, A. W., L. H De Jonge, P. A. Kemme, Z. Mroz, and A. K. Kies. 1997. Non-mineral related effects of phytase in pig diets. pp 92-106 in proceedings of the $6^{\text {th }}$ forum on Animal Nutrition, BASF, Germany.

Juanpere, J., A. M. Perez-Vendrell, E. Angulo, and J. Brufau. 2005. Assessment of potential interactions between phytase and glycosidase enzyme supplementation on nutrient digestibility in broilers. Poultry Science. 84:571-580.

Kocher, A., M. Choct, M. D. Propter, and J. Broz. 2002. Effects of feed enzymes on nutritive value of soybean meal fed to broilers. British Poultry Science. 43: 54-63.

National Research Council. 1994. Nutrient Requirements of Poultry. $9^{\text {th }}$ revised edn. National Academy Press. Washington DC., USA.

Retiman S and S. Frankel. 1957. Calorimetric method for the determination of blood, aminotransferase enzymatic activities. American Journal of Clinical Pathology. 28:56- 63.

Ravindran, V., D. M. Denbow, E. T. Kornegay, Z. Yi, and R. J. Hulet. 1995. Supplemental phytase improves availability of phosphorus in soybean meal for turkey poults. Poultry Science. 74:843-1854.

Ravindran, V., S. Cabahug, G. Ravindran, and W. L. Bryden. 1999. Influence of microbial phytase on apparent ileal amino acid digestibility of feed stuffs for broilers. Poultry Science. 78:699-706.

Rutherfurd, S. M., A. C. Edwards and P. H. Selle. 1997. Effects of phytase on lysine-rice pollard complexes. pp 248 in Manipulating Pig production Vl. Australian. Pig Science Association. Australian.

Panda, A. K., S. V. Rama Rao, M. V. L. N. Raju, S. S. Gajula, and S. K. Bhanja. 2007. Performance of broiler chickens fed low non phytate phosphorus diets supplemented with microbial phytase. The Journal of Poultry Science. 44:258-264.

Saleh, F. H., A. Ohtsuk, T. Tanak, and K. Hayashi. 2004. Carbohdyrases are digested by proteases presented in the enzyme preparations during in vitro digestion. Journal of Poultry Science. 41:229-235.

SAS, Institute. 1990. SAS ${ }^{\circledR}$ User’s Guide, Statistics. Version $6^{\text {th }}$ ed., SAS Institute Inc., NC. USA.

Schutte, J. B., J. D. Jong, W. Smink, and M. Pack. 1997. Replacement value of betaine for Dl-methionine in male broiler chicks. Poultry Science. 76:321-325.

Selle, P. H., V. Ravindran, W. L. Bryden, and T. Scott. 2006. Influence of dietary phytate and exogenous phytase on amino acid digestibility in poultry, a review. Journal of Poultry Science. 43:89-103.

Volovinskaia, V. P. and B. Y. Kelman .1962. Modification of the water 
holding capacity method of meat F. D. industry, 11, 80 Moscow.

Watson D. 1962. Determination of cholesterol in blood. Clinical Chemist Acta. 5:637.

Wu, Y. B., V. Ravindran, D. G. Thomas, M. J. Birtles, and W. H. Hendriks . 2004. Influence of phytase and xylanase, individually or in combination, on performance, apparent metabolisable energy, digestive tract measurements and gut morphology in broilers fed wheat-based diets containing adequate level of phosphorus. British Poultry Science. 45:76-84.
Yonemochi, C., H. Fujisaki and $H$. Takagi. 2003. Effects of amino acid, enzyme mixture and phytase added to low protein and low phosphorus diet on performance and excretion of nitrogen and phosphorus in broilers. Journal of Poultry Science. 40:14-120. 